\title{
METODA REKONSTRUKCIJE ZIDANIH STAVB Z NOTRANJIM JEDROM IZ KRIŽNO LEPLJENIH LESENIH PLOŠČ
}

\author{
RECONSTRUCTION OF MASONRY BUILDINGS WITH AN INNER \\ CORE MADE OF CROSS-LAMINATED TIMBER PANELS
}

\author{
Andrej Štrukelj ${ }^{2}$, Aleš Perjet ${ }^{1}$, Erika Kozem Šilih ${ }^{2}$ \\ 12BUILD4U, Tacenska cesta 125E, 1000 Ljubljana, Slovenija \\ ${ }^{2}$ Univerza v Mariboru, Fakulteta za gradbeništvo, prometno inženirstvo in arhitekturo, Katedra za gradbene konstrukcije, \\ Smetanova 17, 2000 Maribor \\ andrej.strukelj@um.si
}

Prejem rokopisa - received: 2016-06-14; sprejem za objavo - accepted for publication: 2016-06-29

doi:10.17222/mit.2016.107

\begin{abstract}
Članek opisuje tehnologijo izvedbe nove metode rekonstrukcije starih, potresno neodpornih, zidanih stavb, in sicer na način, da v notranjost zidanih stavb vstavimo novo sekundarno leseno konstrukcijo iz križno lepljenih lesenih masivnih plošč (kot notranje jedro stavbe) in jo ustrezno spojimo s staro, primarno zidano, konstrukcijo. S tem načinom utrdimo prvotno potresno neodporno zidano konstrukcijo z novo leseno konstrukcijo, ki prevzame celotno potresno obremenitev. V članku je na vzorčnem primeru zidane stavbe predstavljena tehnologija izvedbe konstrukcijskih ukrepov in računska analiza. Z izračuni smo dokazali možnost utrditve zidane stavbe z ustreznim spajanjem z novim notranjim lesenim jedrom in doprinos izvedenega posega $\mathrm{z}$ gradbeno-fizikalnega vidika.

Ključne besede: rekonstrukcija, zidane stavbe, križno lepljene lesene konstrukcije

The article describes the technology of performing a new reconstruction method for old seismically unsafe masonry buildings in such a way that a new secondary timber construction made of cross-laminated massive timber panels (as the inner core of the building) is embedded in the interior of the masonry buildings and appropriately connected to the old primary masonry construction. With this method the primary, seismically unsafe masonry construction is retrofit with the new timber construction, which resists the entire seismic load. In the article the calculation analysis and the technology of performing construction measures are presented on a case-study masonry building. With a numerical study we have shown the possibility of strengthening an existing building by connecting it with the new inner core as well as the contribution of the intervention to the building-physics aspects.

Keywords: reconstruction, masonry buildings, cross laminated timber panels
\end{abstract}

\section{UVOD}

Na splošno lahko ugotovimo, da je zaradi nekakovostne gradnje ali neustreznega vzdrževanja stanje posameznih vrst obstoječih zgradb v Sloveniji, predvsem stanovanjskih, relativno slabo. ${ }^{1}$ Takšni objekti zaradi energetske neučinkovitosti povzročajo škodo zaradi onesnaževanja okolja, obenem pa zaradi potresno neodporne gradnje predstavljajo grožnjo za življenje ljudi. ${ }^{1}$ Tipičen primer potresno neodporne stanovanjske zgradbe je večetažna nearmirana zidana konstrukcija, zgrajena v obdobju od leta 1920 do 1965 . Takšnih naj bi bilo v Sloveniji skoraj $30 \%$ celotnega stanovanjskega fonda. Ko k temu prištejmo še zidane stavbe iz starejših obdobij, kamor spada večina stavb kulturne dediščine, se omenjeni delež takšnih konstrukcij precej poveča. ${ }^{2}$ Pri rekonstrukciji takšnih objektov pa se lahko srečamo z zahtevo, da se ne dovoljujejo posegi $\mathrm{v}$ zunanji izgled objekta (spomeniškovarstvene zahteve). Pri mnogih tradicionalnih metodah protipotresnih rekonstrukcij stavb je vprašljiva ohranitev zunanjega prvotnega izgleda stavbe. Te metode lahko obenem tudi narekujejo ukrepe, ki še dodatno obremenijo staro konstrukcijo, kar pomeni, da moramo zaradi protipotresnih posegov povečati nosil- nost vsem konstrukcijskim elementom vse do temeljev, ${ }^{2}$ v zgradbo pa se dovede dodatna vlaga (armiranobetonski ometi, armiranobetonski estrihi, injektiranje ipd.), kar povzroča slabe klimatske pogoje $\mathrm{v}$ zgradbi. Ko se srečamo s pogojem, da obstoječih starih konstrukcij ne smemo dodatno obremeniti (npr. zaradi slabih temeljev) ali da moramo upoštevati spomeniškovarstvene zahteve po ohranitvi zunanjega izgleda stavbe, lahko rekonstrukcijo stavbe izvedemo z novim jedrom iz masivnih križno lepljenih (X-lam, CLT) lesenih plošč, ki se uporabljajo za gradnjo sodobnih, tudi večnadstropnih lesenih zgradb. X-lam plošče uvrščamo med masivne konstrukcije, enako kot opečne ali betonske konstrukcije, ${ }^{3}$ vendar pa so bistveno lažje in bolj enostavne za montažo, obenem pa so sposobne prenašati velike obremenitve. Zaradi križno orientiranih lamel lahko te plošče obremenitev prenašajo $\mathrm{v}$ dveh pravokotnih smereh, kar omogoča, da se uporabljajo kot ploskovni nosilni elementi konstrukcije. ${ }^{4} \mathrm{Ob}$ ustrezni povezavi stenskih in stropnih plošč v celotno konstrukcijo z veznimi sredstvi lahko dosežemo, da plošče, ki se uporabljajo za stenske elemente, prevzamejo veliko horizontalno obremenitev tako $\mathrm{v}$ ravnini stene kot pravokotno nanjo, s čimer zagotovimo odlično potresno odpornost zgradbe. X-lam plošče so zaradi 


\section{A. ŠTRUKELJ et al.: METODA REKONSTRUKCIJE ZIDANIH STAVB Z NOTRANJIM JEDROM ...}

lepljenih stikov med posameznimi lamelami zelo toge $\mathrm{v}$ svoji ravnini. Pri prenosu potresne obtežbe se tako večina deformacij izvede $\mathrm{v}$ veznih sredstvih, tj. jeklenih kotnikih, vijakih in žebljih. ${ }^{5-7}$

\section{METODA REKONSTRUKCIJE}

\subsection{Opis tehnologije izvedbe konstrukcijskih in nekon- strukcijskih ukrepov}

Novo metodo rekonstrukcije potresno neodporne zidane stavbe izvedemo na način, da $\mathrm{v}$ njeno notranjost vstavimo jedro iz X-lam plošč s ciljem, da bo nova konstrukcija prenašala vse obtežbe in bo nudila podporo prvotnemu obstoječemu zidovju v primeru potresne obremenitve. Tako dodatno ne obremenjujemo obstoječih konstrukcij, niti ne posegamo $\mathrm{v}$ zunanji izgled stavbe.

Prikaz tehnologije in numerično študijo izvedemo na vzorčnem primeru objekta stare zidane stavbe pravilne oblike, simetrične na obe glavni osi, tlorisnih dimenzij $X$ $=10 \mathrm{~m}$ in $Y=8 \mathrm{~m}$, etažnosti $\mathrm{P}+1$ in skupne višine zidov (brez ostrešja) 5,64 m. Stavba je bila pred rekonstrukcijo stenasta konstrukcija škatlastega tipa. Temelji so bili kamniti, nosilno zidovje je bilo nearmirano, zidano iz polne opeke običajnega formata in malte, debelina zidov je $38 \mathrm{~cm}$. Stropne konstrukcije so bile lesene, sestavljene iz stropnikov, za katere so bili narejeni utori v zidovju. Ostrešje je bilo leseno, pokrito z opečno kritino. Stavba je do sedaj samostojno prenašala lastno in koristno obtežbo.

Stari zidani stavbi najprej odstranimo dotrajane konstrukcijske elemente (streho, vmesne strope, vmesno zidovje, itd.) in izdelamo med zunanjimi zidovi, ki jih ohranimo, novo talno temeljno $\mathrm{AB}$ ploščo. Na nivoju etaž, na notranji strani zidovja, izdelamo po celotni dolžini obodnega zidu $\mathrm{AB}$ vez. V notranjost stavbe nato tik ob obstoječem zidovju na $\mathrm{AB}$ temeljno ploščo vstavimo, po etažah, novo nosilno jedro iz križno lepljenih masivnih lesenih plošč ter ustrezno medsebojno povežemo stare in nove konstrukcije. X-lam obodne stenske plošče in vmesne X-lam stene sidramo $\mathrm{v}$ talno $\mathrm{AB}$ ploščo s pomočjo kovinskih kotnikov, ki jih pritrdi-
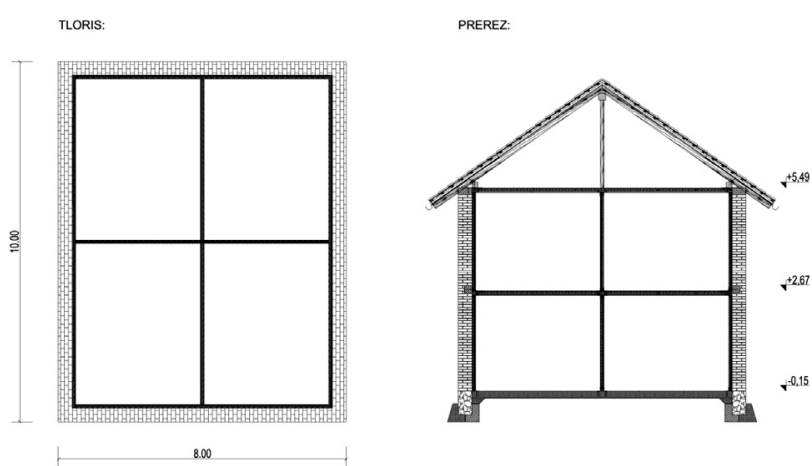

Slika 1: Tloris in prerez rekonstruiranega vzorčnega objekta Figure 1: Ground and cross-section of the case-study building mo stransko na X-lam stenske plošče z obročastimi žeblji, navzdol v AB ploščo pa s sidrnimi vijaki za beton. Vrsto kovinskih kotnikov in razdaljo med njimi določimo s statičnim izračunom v nadaljevanju. Tako postavljene nove $\mathrm{X}$-lam stene sedaj prenašajo prevzete obtežbe na novo izvedeno talno $\mathrm{AB}$ temeljno ploščo. $\mathrm{Na}$ nivoju etaž, kjer imamo pripravljeno $\mathrm{AB}$ vez, s pomočjo kovinskih kotnikov povežemo obstoječe zunanje zidovje z medetažnimi X-lam ploščami novega lesenega jedra. Kotnike pritrdimo v X-lam plošče z obročastimi žeblji, v obstoječe zidove pa $\mathrm{v}$ zato predhodno pripravljeno AB vez s sidrnimi vijaki za beton. Takšna izdelava novega nosilnega jedra iz X-lam plošč, ki so znane po svoji veliki togosti in dobrem prenašanju potresnih obremenitev, ${ }^{3}$ lahko sedaj zagotavlja obstoječi stari konstrukciji stabilnost pri potresni obremenitvi. Predvsem pomembna je izvedba ustreznih detajlov, s katerimi bomo zagotovili ustrezno medsebojno povezanost stare in nove konstrukcije, predvsem na etažnih višinah, posledično pa sodelovanje starih in novih elementov konstrukcijskih sklopov in zagotovitev sistema togih šip v ravnini stropov. Rekonstrukcijo objekta na vrhu zaključimo z novo strešno konstrukcijo, s kritino, ki jo postavimo neposredno na novo X-lam nosilno konstrukcijo. Na tak način obstoječih starih konstrukcij dodatno ne obremenjujemo,
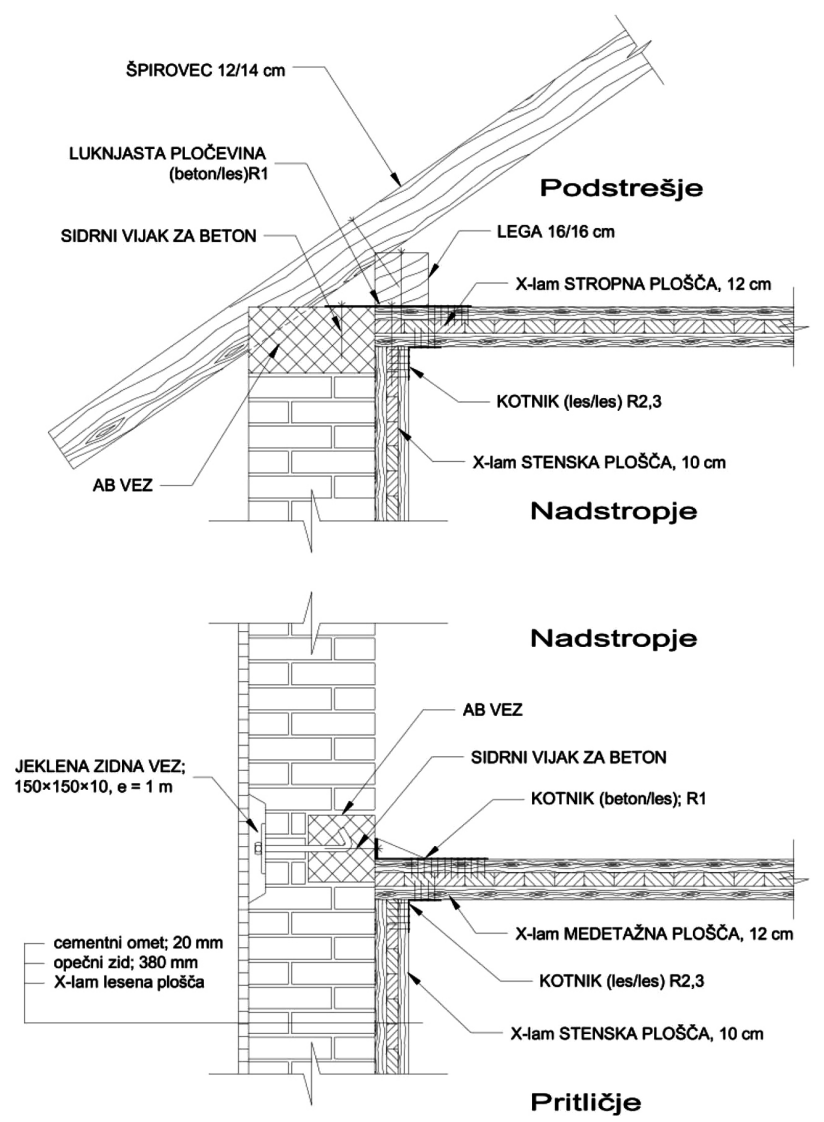

Slika 2: Sidranje zunanjega opečnega zidu na X-lam stropno ploščo na nivoju podstrešja in etaže

Figure 2: Anchoring of the outer brick wall onto the X-lam ceiling panel at the level of the attic and $1^{\text {st }}$ floor 


\section{A. ŠTRUKELJ et al.: METODA REKONSTRUKCIJE ZIDANIH STAVB Z NOTRANJIM JEDROM ...}

niti $\mathrm{z}$ njo ne posegamo $\mathrm{v}$ zunanji izgled stavbe, znotraj objekta pa dobimo novo pomlajeno notranjost stavbe.

Gradbeno-fizikalne zahteve pa rešujemo s sanacijskimi ukrepi, s katerimi izboljšamo bivalno ugodje, varčujemo $\mathrm{z}$ energijo in s tem varujemo okolje. Konstrukcijo saniramo na način, da preprečimo prehode zunanje vlage $\mathrm{v}$ notranjost stavbe, namestimo toplotno izolacijo na zunanje obodne stene ( $\mathrm{v}$ našem primeru na notranji strani), na tla proti terenu in na vrhnjo stropno ploščo.

\subsection{Potresna analiza z, metodo vodoravnih sil}

Za določitev potresnih sil, delujočih na rekonstruiran objekt, uporabimo poenostavljeno metodo analize $\mathrm{s}$ spektrom odziva, ki je znana tudi pod imenom metoda $\mathrm{z}$ vodoravnimi silami. ${ }^{8}$ Po tej metodi v računski analizi potresno obtežbo predpostavimo kot linijsko obtežbo na nivoju vsake etaže, ki jo izračunamo glede na višino in število etaž objekta ter največjo strižno silo (angl. base shear) ob vpetju konstrukcije $\mathrm{v}$ temelje.

\subsubsection{Potresna nosilnost X-lam jedra}

Najprej izračunamo celotno potresno silo, ki deluje na rekonstruiran objekt (Slika 1), pri čemer upoštevamo skupaj mase starih opečnih zidov in nove (lesene) konstrukcije objekta, ki sta medsebojno povezana na nivoju etaž. Na podlagi teh potresnih sil dimenzioniramo spojne elemente, ki medsebojno povezujejo konstrukcijo iz X-lam plošč. Tako mora sedaj v primeru potresa nova X-lam konstrukcija prevzeti tudi potresno obtežbo inercije mase starih zidov.

Vrednost faktorja obnašanja $(q)$, za X-lam plošče, upoštevamo v skladu s priporočili standarda SIST EN 1998-1:2006 ${ }^{8}$ (v nadaljevanju EC8) za lepljene plošče, ki znaša $q=2$. Podatki preizkusa potresnega obnašanja trinadstropne stavbe iz projekta $\mathrm{SOFIE}^{3}$ so sicer pokazali, da bi bil lahko faktor obnašanja takšne stavbe tudi 3 , vendar $\mathrm{v}$ našem primeru prevzamemo bolj konserva-

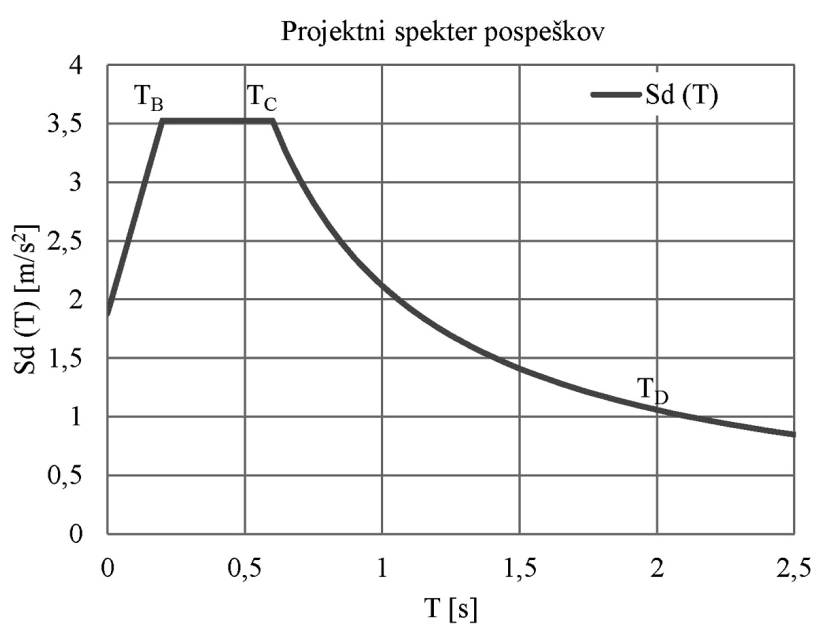

Slika 3: Projektni spekter za X-lam konstrukcijo ( $q=2$, dušenje $5 \%)$ Figure 3: Project spectrum for the X-lam construction $(q=2,5 \%$ damping) tivno predpostavko. Za vzorčni objekt predpostavimo tla tipa $\mathrm{C}\left(S=1.15, T_{B}=0.2 \mathrm{~s}, T_{C}=0.6 \mathrm{~s}, T_{D}=2 \mathrm{~s}\right)$, nihajni čas konstrukcije izračunamo z Enačbo (1) 4.6 iz standarda EC8:

$$
T_{1}=C_{t} \times H^{3 / 4}=0,18 \mathrm{~s}
$$

Vrednost projektnega spektra (Slika 3) za naš nihajni čas znaša $S_{\mathrm{d}}\left(T_{1}\right)=3,36 \mathrm{~m} / \mathrm{s}^{2}$.

Skupno efektivno maso za posamezno etažo določimo z upoštevanjem prispevka mas konstrukcij na nivojih etaž, tj. deleži zunanjih opečnih zidov, $A B$ vezi, $\mathrm{X}$-lam stenskih plošč z oblogami, X-lam medetažnih plošč z estrihi ter strehe. Efektivna masa konstrukcije nad pritličjem znaša 90 ton, konstrukcije nad nadstropjem pa 53,4 tone.

Celotno potresno prečno silo izračunamo z Enačbo (2) 4.5 iz EC8:

$$
F_{\text {b,celotna, } \mathrm{X}, \mathrm{Y}}=481,76 \mathrm{kN}
$$

Po višini konstrukcije razporedimo potresne sile $\mathrm{z}$ Enačbo (3) 4.11 iz EC8:

$$
\begin{aligned}
& F_{\text {prit, }, Y}=220,47 \mathrm{kN} ; \\
& F_{\text {nad, }, \mathrm{Y}}=261,29 \mathrm{kN}
\end{aligned}
$$

Upoštevamo še vpliv naključne torzije s pomočjo Enačbe (4) 4.12 iz EC8, iz česar sledi povečanje učinka vpliva vodoravnih potresnih sil:

$$
\begin{aligned}
& F_{\text {b, celotna }, \mathrm{X}, \mathrm{Y}}=770,82 \mathrm{kN} ; \\
& F_{\text {prit, }, \mathrm{Y}}=352,75 \mathrm{kN} ; \\
& F_{\text {nad }, \mathrm{X}, \mathrm{Y}}=418,06 \mathrm{kN}
\end{aligned}
$$

Za preverjanje mejnega stanja nosilnosti X-lam masivne konstrukcije (njenih kovinskih spojnih elementov nameščenih na spojih med stenami in ploščami) moramo izpolniti pogoj, da je projektna vrednost učinka vpliva pri projektni potresni kombinaciji manjša ali kvečjemu enaka odgovarjajoči projektni nosilnosti kovinskega spojnega elementa. Projektna nosilnost kovin-

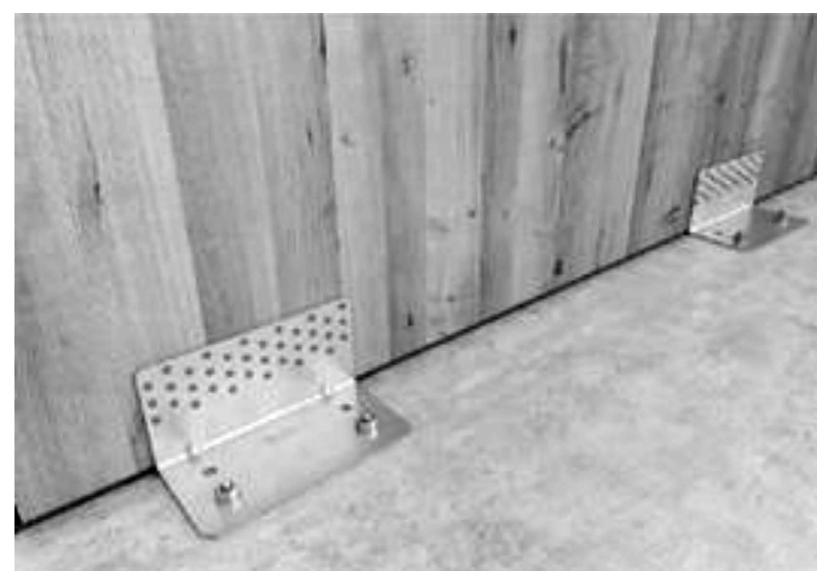

Slika 4: Sidranje X-lam stenskih plošč s kotniki za prevzem strižnih obremenitev na spoju beton/les ${ }^{9}$

Figure 4: Anchoring of X-lam wall panels with steel angular brackets for the transfer of shear load in the concrete-timber joint ${ }^{9}$ 


\section{A. ŠTRUKELJ et al.: METODA REKONSTRUKCIJE ZIDANIH STAVB Z NOTRANJIM JEDROM ...}

skega spojnega elementa se računa po pravilih, ki veljajo za uporabljen material (uporabljajo se karakteristične vrednosti lastnosti materiala $f_{k}$ in parcialni faktorji varnosti $\gamma_{\mathrm{m}}$ ). Za spojne elemente na vzorčnem primeru bomo uporabili tipske kotnike (Slika 4) podjetja Rothoblaas. ${ }^{9}$ Ko dimenzioniramo spojne elemente za prevzem potresne obremenitve med križno lepljenimi lesenimi stenskimi in stropnimi ploščami, računamo s kotniki za prenos strižnih sil. Ker imamo precej dolge stene in nizko zgradbo, do dvižnih sil v vogalih sten načeloma ne prihaja.

Dolžine sidranja X-lam sten izračunamo ob dejstvu, da imamo v vsaki smeri zgradbe 3 linije enako dolgih sten (Slika 1). Srednji steni, ki sta dostopni z obeh strani, lahko tako z vsake strani tudi sidramo, do zunanjih parov sten pa lahko dostopamo le $\mathrm{z}$ ene strani. Zato $\mathrm{v}$ račun $\mathrm{v}$ vsaki smeri vzamemo 4 efektivne dolžinske linije sten (enačba (5)):

$$
\begin{aligned}
& L_{\text {sten,X }}=4 \times 9,04 \mathrm{~m} ; \\
& L_{\text {sten, },}=4 \times 7,04 \mathrm{~m}
\end{aligned}
$$

Izračunamo strižne sile po tekočem metru v posamezni etaži. Kasneje bomo izračunali, koliko kotnikov potrebujemo v smereh $\mathrm{X}$ in $\mathrm{Y}$.

Potresne sile na tekoči meter sten na koti vpetja $\mathrm{V}$ pritličju (spoj talne $\mathrm{AB}$ plošče in X-lam stenskih plošč pritličja) so:

$$
\begin{aligned}
& F_{\mathrm{b}, \mathrm{X}}^{\prime}=\frac{F_{\mathrm{b}, \text { celotna, } \mathrm{X}, \mathrm{Y}}}{L_{\text {sten } \mathrm{X}}}=21,31 \frac{\mathrm{kN}}{\mathrm{m}} \\
& F_{\mathrm{b}, \mathrm{Y}}^{\prime}=\frac{F_{\mathrm{b}, \text { celotna }, \mathrm{X}, \mathrm{Y}}}{L_{\text {sten, } \mathrm{Y}}}=27,37 \frac{\mathrm{kN}}{\mathrm{m}}
\end{aligned}
$$

Za prevzem sil izberemo kotnik TITAN TCN 200 za obremenitve na polnih stenah, ki ga na tem nivoju etaže pritrjujemo navzdol v AB talno ploščo s kemijskim sidrom tipa AB1 M12 $\times 103$ in stransko v les z žeblji LBA $\phi 4 \times 60$. Sile na vrhu sten so tako rekoč enake kot na dnu sten, vendar tu izberemo drugačen kotnik, tj. WBR90, ki ga na tem nivoju etaže pritrjujemo navzgor in stransko v les z žeblji LBA $\phi 4 \times 60$.

Potresne sile na tekoči meter stene na koti nadstropja spodaj (spoj medetažne X-lam plošče in X-lam sten nadstropja) in na vrhu nadstropja (spoj X-lam stropne plošče in X-lam sten nadstropja) pa so:

$$
F_{\mathrm{b}, \text { nad }, \mathrm{X}}^{\prime}=\frac{F_{\mathrm{b}, \text { nad, } \mathrm{X}, \mathrm{Y}}}{L_{\mathrm{sten, \textrm {X }}}}=11,56 \frac{\mathrm{kN}}{\mathrm{m}}
$$

$$
F_{\mathrm{b}, \text { nad, } \mathrm{Y}}^{\prime}=\frac{F_{\mathrm{b}, \text { nad }, \mathrm{X}, \mathrm{Y}}}{L_{\mathrm{sten}, \mathrm{Y}}}=14,84 \frac{\mathrm{kN}}{\mathrm{m}}
$$

V obeh primerih:

$$
\begin{aligned}
& F_{2 / \text { a, nad, spod, } \mathrm{X}}=\frac{F_{\text {nad, } \mathrm{X}}}{L_{\mathrm{CLT}, \text { stenaX }} \times 4}=11,56 \frac{\mathrm{kN}}{\mathrm{m}} \\
& F_{2 / 3, \text { nad, spod, } \mathrm{Y}}=\frac{F_{\text {nad, } \mathrm{Y}}}{L_{\mathrm{CLT} \text {, stena } \mathrm{Y}} \times 4}=14,84 \frac{\mathrm{kN}}{\mathrm{m}}
\end{aligned}
$$

izberemo kotnik WBR90, ki ga na tem nivoju etaže pritrjujemo navzdol in stransko v les z žeblji LBA $\phi 4 \times$ 60.

Potrebne razdalje med posameznimi spojnimi sredstvi $\left(L_{\text {kotnik }}\right) \mathrm{v}$ smeri $\mathrm{X}$ in Y so izračunane kot razmerje med projektnimi vrednostmi odpornosti spojnih sredstev in strižnimi silami, delujočih po tekočem metru objekta $\mathrm{v}$ smereh $X$ in $Y$ (Tabela 1). Projektne vrednosti odpornosti spojnih sredstev $\left(R_{\mathrm{d}}\right)$ se izračunajo iz lastnosti spojnih sredstev za posamezne načine pritrjevanja.

\subsubsection{Potresno sidranje starih zidov v X-lam jedro}

$\mathrm{S}$ pomočjo iste metode izračunamo potresne sile, ki jih povzroči masa zunanjih opečnih zidov, povezanih na nivoju etaž na notranje jedro iz križno lepljenih lesenih masivnih plošč. $\mathrm{V}$ tem primeru dimenzioniramo spojne elemente, potrebne za vpetje zunanjih opečnih zidov na notranje leseno jedro, ki bodo preprečili porušitev starih zidov izven svoje ravnine (Slika 2). Pri izračunu potresnih sil, ki jih povzročajo stari zidovi na konstrukcijo, bomo predpostavili faktor obnašanja $q=1$, ker ne pričakujemo disipiranja energije $\mathrm{v}$ spojih med starimi zidovi in novo konstrukcijo. Računamo $\mathrm{z}$ elastičnim spektrom odziva, njegova vrednost za izračunan primer znaša $S_{\mathrm{d}}\left(T_{1}\right)=6,53 \mathrm{~m} / \mathrm{s}^{2}$.

Skupna efektivna masa za posamezno etažo je določena $\mathrm{z}$ upoštevanjem prispevka mas zunanjih opečnih zidov in $A B$ vezi na nivojih etaž, (deleži zunanjih opečnih zidov in $\mathrm{AB}$ vezi). Za zunanje opečne zidove, ki jih sidramo na koti etaže znaša 66,8 t, za zidove, ki jih sidramo na vrhu prvega nadstropja pa $34,1 \mathrm{t}$.

Celotna potresna prečna sila, ki jo povzroči opečni zid, z upoštevanjem vpliva naključne torzije, znaša $F_{\text {b,zid,X,Y }}=1065,17 \mathrm{kN}$. Silo razdelimo še po višini, tako dobimo silo, ki deluje nad pritličjem $F_{\text {zid,prit,X,Y }}=519,46$ $\mathrm{kN}$ ter silo, ki deluje nad nadstropjem $F_{\text {zid,nad,X,Y }}=545,71$ $\mathrm{kN} ; \quad F_{\text {zid,pritX,Y }}=516,40 \mathrm{kN} ; \quad F_{\text {zid,nad,X,Y }}=542,51 \mathrm{kN}$.

Opečne zidove lahko sidramo le $\mathrm{v}$ zunanjo konturo lesenega jedra. Proporcionalni delež sile, ki deluje na

Tabela 1: Raster veznih sredstev za X-lam jedro

Table 1: The spacing of fasteners in the X-lam core

\begin{tabular}{|c|c|c|c|c|c|c|c|}
\hline Nivo pritrditve & Kotnik (X-lam) & Način pritrditve & $R_{\mathrm{d}}(\mathrm{kN})$ & $F_{\mathrm{b}, \mathrm{X}}^{\prime}(\mathrm{kN} / \mathrm{m})$ & $F_{\mathrm{b}, \mathrm{Y}}^{\prime}(\mathrm{kN} / \mathrm{m})$ & $L_{\text {kotnik,X}}(\mathrm{m})$ & $L_{\mathrm{kotnik}, \mathrm{Y}}(\mathrm{m})$ \\
\hline pritličje spodaj & TCN 200 & beton/les & 20,2 & 21,31 & 27,37 & 0,95 & 0,74 \\
\hline pritličje zgoraj & WBR 90 & les/les & 9,02 & 21,31 & 27,37 & 0,42 & 0,33 \\
\hline nadstropje spodaj & WBR 90 & les/les & 9,02 & 11,56 & 14,84 & 0,78 & 0,61 \\
\hline nadstropje zgoraj & WBR 90 & les/les & 9,02 & 11,56 & 14,84 & 0,78 & 0,61 \\
\hline
\end{tabular}




\section{A. ŠTRUKELJ et al.: METODA REKONSTRUKCIJE ZIDANIH STAVB Z NOTRANJIM JEDROM ...}

leseno jedro v smeri izven svoje ravnine, dobimo tako, da delimo celotno potresno silo v etaži s celotno dolžino oboda zgradbe. Celotna dolžina sidranja znaša:

$$
L_{\text {zid,tot }}=2 \times 9,24 \mathrm{~m}+2 \times 7,24 \mathrm{~m}=32,96 \mathrm{~m}
$$

Izračunamo natezne sile $\left(F_{1}\right)$ po tekočem metru $\mathrm{v}$ posamezni etaži, na podlagi katerih bomo določili, koliko kotnikov potrebujemo v smereh $X$ in $Y$.

Na koti nadstropja (spoj medetažne lesene plošče in zunanjih opečnih zidov) znaša sila:

$$
F_{1, \text { nad }}^{\prime}=\frac{F_{\text {zid, prit, } \mathrm{X}, \mathrm{Y}}}{L_{\text {zid, tot }}}=15,76 \frac{\mathrm{kN}}{\mathrm{m}}
$$

Predpostavimo, da je opečni zid v svoji ravnini sposoben prenesti silo lastne inercije sam. Izberemo kotnik WHT340 za natezni spoj les/beton, ki ga na tem nivoju etaže pritrjujemo stransko s kemijskim sidralom tipa VINYLPRO $1 \times$ M $16 \times 160 \mathrm{v}$ AB vez in navzdol $\mathrm{z}$ Žeblji LBA $\phi 4 \times 60 \mathrm{v}$ les.

Na koti podstrešja (spoj medetažne lesene plošče in zunanjih opečnih zidov) pa je sila:

$$
F_{1, \text { podd }}^{\prime}=\frac{F_{\text {zid, nad, } \mathrm{X}, \mathrm{Y}}}{L_{\text {zid, tot }}}=16,56 \frac{\mathrm{kN}}{\mathrm{m}}
$$

Izberemo luknjane plošče WHT 440 za natezni spoj les/beton, ki ga na tem nivoju etaže pritrjujemo navzdol $\mathrm{v} A B$ vez $\mathrm{s}$ kemijskim sidralom tipa VINYLPRO M16x190 in navzdol v les z žeblji LBA $\phi 4 \times 60$. Razdalje med veznimi sredstvi so podane v Tabeli 2.

Tabela 2: Raster veznih sredstev za pritrjevanje starega zidu v X-lam jedro

Table 2: The spacing of fasteners for attaching the old masonry wall to the X-lam core

\begin{tabular}{|c|c|c|c|c|c|}
\hline $\begin{array}{c}\text { Nivo } \\
\text { pritrditve }\end{array}$ & $\begin{array}{c}\text { Kotnik } \\
\text { (zid) }\end{array}$ & $\begin{array}{c}\text { Način } \\
\text { pritrditve }\end{array}$ & $\begin{array}{c}\mathrm{R}_{\mathrm{d}} \\
(\mathrm{kN})\end{array}$ & $\begin{array}{c}\mathrm{F}_{1, X, Y} \\
(\mathrm{kN} / \mathrm{m})\end{array}$ & $\begin{array}{c}L_{\mathrm{kotnik}, \mathrm{zid}, \mathrm{XY}} \\
(\mathrm{m})\end{array}$ \\
\hline nadstropje & WHT340 & beton/les & 36,02 & 15,76 & 2,28 \\
\hline podstrešje & WHT440 & beton/les & 22,58 & 16,56 & 1,36 \\
\hline
\end{tabular}

\section{REZULTATI IN DISKUSIJA}

\subsection{Rekonstrukcija}

Potresno obremenitev mora $\mathrm{v}$ rekonstruiranem objektu prevzeti novo vstavljena konstrukcija iz X-lam plošč, oziroma spojna sredstva (kovinski kotnik), ki povezujejo elemente X-lam konstrukcije (stenske in medetažne plošče). Za zagotovitev nosilnosti X-lam konstrukcije ob delovanju potresnih sil potrebujemo zadostno število spojnih sredstev, ki bodo prevzele obremenitev. Prav tako potrebujemo za zagotovitev stabilnosti zunanjih opečnih zidov proti prevrnitvi izven svoje ravnine zadostno število spojnih sredstev (kovinski kotniki, luknjane plošče), ki povezujejo novo X-lam konstrukcijo s starimi zidovi na nivoju etaž. Z numerično študijo smo dokazali, da je možno potresne sile za dvoetažni objekt prevzeti s standardnimi veznimi sredstvi na relativno enostaven način.

\subsection{Energetska sanacija}

$\mathrm{Z}$ novo izvedeno sekundarno konstrukcijo $\mathrm{v}$ notranjosti objekta, s katero potresno zavarujemo staro zidovje, prepolovimo toplotno prehodnost na zidnem konstrukcijskem sklopu že brez dodajanja toplotne izolacije. Uporabljamo namreč dokaj izolativen material (masivne lesene plošče), kar samo po sebi zmanjša prehod skozi rekonstruiran konstrukcijski sklop. Medsebojni primerjavi toplotnih prehodnosti skozi zidni konstrukcijski sklop smo izračunali s programom "U-Wert Rechner". ${ }^{10}$ Toplotna prevodnost za zunanji ovoj konstrukcije znaša $1,19 \mathrm{~W} / \mathrm{m}^{2} \mathrm{~K}$ za prvoten ter $0,57 \mathrm{~W} / \mathrm{m}^{2} \mathrm{~K}$ za rekonstruiran objekt.

\subsection{Parametrična študija}

$\mathrm{V}$ študiji obravnavamo tri vzorčne primere po novi metodi rekonstruiranih objektov enakih tlorisnih dimenzij $8 \times 10 \mathrm{~m}$ in etažne višine $2,82 \mathrm{~m}$. Parameter, ki ga v študiji spreminjamo, je etažnost objektov, ki jo spreminjamo od ene do treh etaž. Ostalih parametrov $v$ tej študiji ne spreminjamo.

Ob zviševanju števila etaž objektov se potresna sila ob vpetju močno povečuje, kar je logična posledica delovanja večje celotne mase objekta $\mathrm{z}$ več etažami. Vrednosti potresnih sil nato proti vrhu naših vzorčnih primerov objekta $\mathrm{v}$ vsaki etaži padajo, saj je bila $\mathrm{v}$ osnovi naša predpostavka, da so vzorčni primeri objektov pravilni po višini in se masa postopoma zmanjšuje od temeljev proti vrhu. Med vzorčnima primeroma objekta "P" in "P + 1" je precejšnja razlika v silah, ker smo pri izvedbi vzorčnega primera objekta "P" še pred t. i. platojem projektnega spektra pospeškov, z vzorčnim primerom objekta "P + 1" pa smo že v platoju projektnega spektra pospeškov, kjer se generirajo tudi največje sile. Obenem pa vidimo, da pri vzorčnem primeru objekta "P +2 " razmerje velikosti skupne potresne sile in lastne teže objekta (Slika 5) pade. Če bi parametrično študijo pri enakih pogojih nadaljevali (na primer "P + 3" itd.), bi to razmerje še nadalje padalo, ker bi se vse bolj oddaljevali od platoja spektra pospeškov in bi normirana potresna obremenitev padala. Predvide-

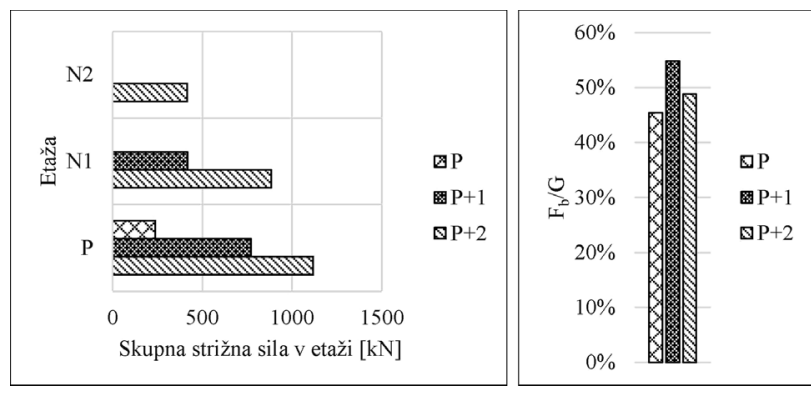

Slika 5: Prikaz velikosti skupnih potresnih strižnih sil, ki delujejo po posameznih etažah in razmerja med celotno potresno silo in skupnimi lastnimi težami vzorčnih objektov

Figure 5: Total seismic shear forces in each floor and the ratios between the total seismic force and self-weights of case-study buildings 


\section{A. ŠTRUKELJ et al.: METODA REKONSTRUKCIJE ZIDANIH STAVB Z NOTRANJIM JEDROM ...}

vamo lahko torej, da se stroški rekonstruiranja (na uporabno površino) po novi metodi na račun veznih sredstev ne bi nujno linearno bistveno povečevali, pri rekonstrukcijah večetažnih stavb. Obenem pa moramo pri rekonstrukcijah upoštevati tudi dejstvo, da so stroški pripravljalnih in zemeljskih del, ureditve odvodnjavanj v okolici objekta, rekonstrukcije in sanacije vdora zunanje vode $\mathrm{v}$ objekt itd. (torej vsa dela do kote $+0,00 \mathrm{~m}$ ) skoraj enaki za manj etažne kot za večetažne stavbe, kar vpliva na končno ceno rekonstrukcije po enoti rekonstruirane površine.

\subsection{Stroškovna ocena}

Za izvedbo rekonstrukcije po novi metodi protipotresne utrditve zidane stavbe bi celotni ocenjeni stroški investicije izvedbe takšne rekonstrukcije (vključeni stroški izvedbe konstrukcijskih ukrepov, sanacijskih ukrepov in izvedbe novih instalacij) znašali okoli 820 EUR $/ \mathrm{m}^{2}$ neto. Primerjava zgolj stroškov konstrukcijskih ukrepov po novi tehnologiji v primerjavi z eno od tradicionalnih metod rekonstrukcije protipotresne utrditve zidanih stavb je sledeča:

Rekonstrukcija s stabilizacijo zidane stavbe $\mathrm{z}$ notranjim jedrom iz križno lepljenih lesenih plošč: 346 $\mathrm{EUR} / \mathrm{m}^{2}$ (strošek vključuje že novo streho in delno toplotno izolirane zunanje stene zaradi uporabe izolativnega materiala).

Rekonstrukcija obstoječih zidov zidane stavbe $\mathrm{z}$ oblaganjem $\mathrm{z}$ armiranimi ometi in izvedba utrditvenih armiranobetonskih estrihov: $348 \mathrm{EUR} / \mathrm{m}^{2}$.

Primerjava pokaže, da gre $\mathrm{v}$ osnovi za praktično enake stroške, vendar pa nova metoda ugodno vpliva tudi na energetski vidik zaradi uporabe bolj izolativnega materiala. To pomeni, da gre pri celotni investiciji vsekakor za ugodnejšo tehnologijo v primerjavi z ostalimi.

\section{ZAKLJUČEK}

Nova tehnologija izvedbe X-lam notranjega jedra kot sekundarnega nosilnega konstrukcijskega sistema $\mathrm{v}$ notranjosti obstoječe zidane stavbe, ki zahteva pravilno in smiselno izvedbo posameznih detajlov spojitve stare in nove konstrukcije po posameznih etažah, predstavlja učinkovit sistem protipotresne rekonstrukcije primarne stare potresno neodporne stavbe in zvišuje obstoječi konstrukciji stabilnost pri potresni obremenitvi. Rekonstrukcijo lahko izvedemo brez večjih posegov v zunanji izgled objekta (v primeru stavbe pod spomeniškim varstvom) ter ne predstavlja dodatnih obremenitev za obstoječe stare konstrukcije. Računsko smo dokazali, da lahko z ustrezno izvedenimi načini spajanj starih in novih konstrukcijskih elementov prevzamemo potresno obremenitev, ki bi delovala na tako rekonstruiran objekt. Ob izvedbi rekonstrukcijskega posega se izboljšajo tudi energetski pogoji v stavbi, ker oblagamo obstoječe staro toplotno prehodno zidovje $\mathrm{z}$ novim toplotno izolativnim materialom (masivnimi lesenimi ploščami), kar samo po sebi zmanjša prehod toplote skozi rekonstruiran konstrukcijski sklop. Stroškovna analiza ne pokaže bistvenih razlik $\mathrm{v}$ primerjavi s konvencionalnimi metodami potresne rekonstrukcije, vendar sistem zaradi svoje večfunkcionalnosti predstavlja bolj racionalno investicijo, saj ob enakem strošku omogoča celovito prenovo objektov.

\section{LITERATURA}

${ }^{1}$ G. Černe, I. Janežič, Uvod, Sanacija in rekonstrukcija zgradb: Zbornik referatov Gradbeni inštitut ZRMK, Ljubljana 1999, 5-7

${ }^{2}$ S. Gostič, A. Mezgec, R. Žarnić, Protipotresne utrditve zidanih konstrukcij s CFRP kompoziti, Gradbenik, 3 (2005), 37-41

${ }^{3}$ S. Gagnon, C. Pirvu, CLT handbook: Cross - laminated timber, Canadian ed., FPInnovations, Québec 2011

${ }^{4}$ K. Štraus, Analiza dinamičnega odziva 7-etažne lesene masivne konstrukcije na potresni mizi, FGG, Ljubljana 2008

${ }^{5}$ J. Jančar, B. Dujič, Primerjava lesenih masivnih panelov sestavljenih iz različno križno spojenih lesenih struktur, 33. Zborovanje gradbenih konstruktorjev Slovenije, Bled 2011

${ }^{6}$ B. Dujič, R. Žarnić, M. Kitek Kuzman, Vrednotenje potresne odpornosti lesene gradnje, Gradnja z lesom - izziv in priložnost za Slovenijo, Univerza v Ljubljani, Biotehniška fakulteta, Oddelek za lesarstvo, Ljubljana 2009, 176-180

${ }^{7}$ I. Sustersic, M. Fragiacomo, B. Dujic, Seismic Analysis of CrossLaminated Multistory Timber Buildings Using Code-Prescribed Methods: Influence of Panel Size, Connection Ductility, and Schematization. Journal of Structural Engineering, 142 (2016) 4, doi: 10.1061/(ASCE)ST.1943-541X.0001344

${ }^{8}$ SIST EN 1998-1: 2006, Evrokod 8: Projektiranje potresnoodpornih konstrukcij - 1. del: Splošna pravila, potresni vplivi in pravila za stavbe, Slovenski inštitut za standardizacijo, Ljubljana, 2006

${ }^{9}$ Plošče in spojniki za les, Katalog podjetja Rohtoblaas, http://www.rothoblaas.com/en/si/catalogues/fastening-systems.html, 30. 3.2016

${ }^{10}$ Računalniški program U-wert Rechner, https://www.u-wert.net/, 23. 3. 2016 